\title{
Model Organizma Galleria mellonella L.'da Bakır Nanopartiküllerinin Oksidatif Stres Üzerine Etkilerinin Değerlendirilmesi
}

\author{
Benay TUNCSOY \\ Adana Alparslan Türkeş Bilim ve Teknoloji Üniversitesi, Mühendislik Fakültesi, Biyomühendislik Bölümü, Adana, Türkiye
}

Atıf yapmak için: Tunçsoy, B. (2021). Model Organizma Galleria mellonella L.'da Bakır Nanopartiküllerinin Oksidatif Stres Üzerine Etkilerinin Değerlendirilmesi. Anadolu Çev. ve Hay. Dergisi, 6(5), 278-284.

How to cite: Tunçsoy, B. (2021). Evaluation of the Effects of Copper Nanoparticles on Oxidative Stress in the Model Organism Galleria mellonella L. J. Anatolian Env. and Anim. Sciences, 6(5), 278-284.

iD : https://orcid.org/0000-0003-4361-3475

*Sorumlu yazarın: Benay TUNÇSOY

Adana Alparslan Türkeş Bilim ve Teknoloji Üniversitesi, Mühendislik Fakültesi,

Biyomühendislik Bölümü, Adana, Türkiye

ه: btuncsoy@atu.edu.tr
Öz: Yapılan çalışmada farklı derişimlerdeki bakır oksit nanopartiküllerinin (10, 100 ve $1000 \mu \mathrm{g} / \mathrm{mL}$ ) Galleria mellonella larvalarının orta barsak ve yağ dokusundaki katalaz (CAT), superoksit dismutaz (SOD), glutatyon peroksidaz (GPx), glutatyon-s-transferaz (GST) ve asetilkolinesteraz (AChE) aktiviteleri üzerine etkileri araştırılmıştır. Farklı derişimlerdeki bakır oksit nanopartiküllerine maruz bırakılan G. mellonella larvalarının orta barsak ve yăg dokularında tüm uygulama gruplarında CAT, SOD ve AChE aktivitelerinde azalma tespit edilirken, $100 \mu \mathrm{g} / \mathrm{mL}$ bakır oksit nanopartikülü uygulaması yapılan grupta GPx aktivitelerinde artış meydana geldiği belirlenmiştir. Ayrıca GST aktivitesinde tüm uygulama gruplarında yağ dokuda azalma, orta barsakta ise artış meydana geldiği tespit edilmiştir. Genel olarak, bu bulgular, G. mellonella larvalarında bakır oksit nanopartikülünün toksisitesi sonucunda reaktif oksijen türlerinin birikimi nedeniyle oksidatif stresin meydana geldiğini göstermektedir.

Anahtar kelimeler: Antioksidan enzimler, bakır nanopartikülleri, Galleria mellonella.

\section{Evaluation of the Effects of Copper Nanoparticles on Oxidative Stress in the Model Organism Galleria mellonella $\mathbf{L}$.}

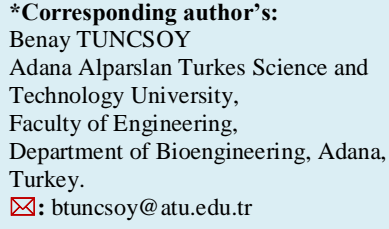

\begin{abstract}
In this study, the effects of copper oxide nanoparticles at different concentrations $(10,100$ and $1000 \mu \mathrm{g} / \mathrm{mL}$ ) on catalase (CAT), superoxide dismutase (SOD), glutathione peroxidase (GPx), glutathione-s-transferase (GST) and acetylcholinesterase (AChE) activities were investigated in the midgut and fat body of Galleria mellonella larvae. It was determined that GPx activities increased in the group exposed to $100 \mu \mathrm{g} / \mathrm{mL}$ copper oxide nanoparticles, whereas a decrease in CAT, SOD and AChE activities was observed in midgut and fat body of G. mellonella larvae exposed to all copper oxide nanoparticles applied groups. Moreover, GST activity decreased in fat body in all applied groups, while an increased was observed in midgut of $G$. mellonella larvae when exposed to copper oxide nanoparticles. Overall, these findings indicate that oxidative stress occurs due to the accumulation of reactive oxygen species as a result of the toxicity of the copper oxide nanoparticle of G. mellonella larvae.
\end{abstract}

Keywords: Antioxidant enzymes, copper nanoparticles, Galleria mellonella. 


\section{GíRiş}

Bakır nanopartikülleri biyosidal aktivite ve optik görüntüleme gibi özelliklerinden dolayı son yıllarda önemli ölçüde ilgi görmekte, özellikle biyomedikal ve endüstriyel uygulamalarda sıklıkla bu nanopartiküllerden yararlanılmaktadır. Buna ek olarak, yüksek elektriksel ve sıcaklık iletkenliği gibi fizikokimyasal özelliklerinden dolayı termal, elektrikli cihazlarda ve sensörlerde kullanılmaktadır (Hannig vd., 2007; Nations vd., 2015; Zhou vd., 2016). Buna rağmen farklı deneysel model sistemlerde yüksek toksisiteye neden olduğu da bilinmektedir.

Metal oksit nanopartikülleri, oksidatif strese ve hücresel toksisiteye yol açan normal hücresel aktivitelerin deregülasyonuna neden olmaktadır. Bu nedenle, oksidatif stres nanotoksisitenin en önemli nedenlerinden biri olarak kabul edilmekte ve nanopartiküllerin toksik etkilerinin değerlendirilmesinde biyoindikatör olarak kullanılmaktadır (Libralato vd., 2017).

Bakır maruziyetinin önemli ölçüde hücre içi reaktif oksijen türlerinin birikimine yol açtığı farklı hücre kültürü modelleri ile zebra balığı, karides gibi akuatik model organizmalarda da toksik etkilere neden olduğu yapılan çalışmalarda tespit edilmiştir (Ivask vd., 2014). Buna ek olarak, A549 hücrelerinde bakır oksit nanopartiküllerinin oksidatif stresle ilişkili olan sistein, glutatyon, disülfür gibi metabolitlerin düzenlenmesini indüklediği ve GPx, SOD, GST, lipid peroksidasyon ve CAT gibi antioksidan ve detoksifikasyon enzimlerinin aktivitelerinin fare hipokampal $\mathrm{H} 122$ hücrelerinde değişikliklere de neden olduğu bildirilmiştir (Boyles vd., 2016; Niska vd., 2015). Böceklerde ise, reaktif oksijen türlerinin oluşumunun artması, mideye alınan besinlerin absorbsiyonunu olumsuz etkilemekte ve orta barsak hücrelerinde de oksidatif zarara neden olabilmektedir (Bi \& Felton, 1995).

Deneyde kullanılan büyük bal mumu güvesi Galleria mellonella, son y1llarda birçok alanda deneysel çalışmalarda model organizma olarak kullanılmaktadır. Tıp alanındaki deneysel çalışmalarda kullanılan farenin yetiştirilmesinin zor ve pahalı olması, ayrıca etik ve legal sorunlara yol açması model organizma olarak omurgasızların kullanılmasına olanak sağlamaktadır. $G$. mellonella gibi türler, üretimi basit ve pahalı olmamasından dolayı iyi bir model organizmadır. Ayrıca bu türe ait larvaların ticari yönden üretime uygun olması, oda sıcaklığında üretiminin kolaylıkla ve kısa sürede yapılabilmesi bu türü diğer omurgasız canlılardan da ayırt etmektedir. Bunun yanı sira, G. mellonella' nin memelilerle benzer doğal bağışıklık sistemine sahip olması da onun uygun bir model organizma olabilmesini sağlamaktadır. Bu bilgiler ışığında, çalışmada kullanımı hızla artan bakır oksit nanopartikülünün model organizma olarak kullanılan G. mellonella larvalarının orta barsak ve yağ dokularında antioksidan sistem üzerine etkilerinin belirlemek amaciyla SOD, CAT, GPx, GST ve AChE enzim aktivitelerinin tespit edilmesi hedeflenmektedir.

\section{MATERYAL VE METOT}

Deney Böceklerinin Elde Edilmesi: $\mathrm{Bu}$ çalışmada kullanılan $G$. mellonella kültürünün devamı, $30 \pm 1^{\circ} \mathrm{C}$ sıcaklık ve $\% 65 \pm 5$ bağıl nem içeren böcek kültür odalarında, böceğin yumurtadan yeni çıkmış larvalarının yarı sentetik besin ile beslenmesiyle sağlanmıştır.

G. mellonella larvalarının beslenmesi için kepek, gliserin, bal, saf su ve petekten oluşan besin karışımı kullanılmıştır (Bronskill, 1961). Hazırlanan besin, bir litrelik kavanozlara yaklaşık 1/3 oranında konulduktan sonra, içerisine 10-15 adet ergin dişi ve erkek bireyler bırakılmıştır. Kavanozların kapaklarına dişilerin yumurta bırakmalarını sağlamak amacıyla bırakılan kâğıtlar, günaşırı değiştirilerek içerisinde yeni besin bulunan farklı kavanozlara aktarılmıştır. Gelişimlerini üçüncü evreye kadar tamamlayan larvalar, besin ortamından alınarak deneylerde kullanılmıştır.

Bakır oksit

nanopartiküllerinin karakterizasyonu: Deneylerde partikül büyüklüğü 50 nm'den küçük olan bakır oksit nanopartikülü (SigmaAldrich) kullanılmıştır. Çalışmada $G$. mellonella larvalarına uygulanan bakır oksit nanopartiküllerinin karakterizasyonu, Portekiz'de Algarve University, Faculty of Science and Technology (CIMA)' da transmisyon elektron mikroskobu (TEM) ve dinamik 1 şı saçılımı (DLS) cihazı ile yapılmıştır. Karakterizasyon yöntemlerine ilişkin daha fazla ayrıntı önceki çalışmalarda bildirilmiştir (Gomes vd., 2011; Sezer Tuncsoy vd., 2019; Sezer Tuncsoy, 2020).

Farklı derişimlerdeki bakır oksit nanopartiküllerinin uygulanması: Besin ortamından alınacak üçüncü evre larvalar, kontrol grubu ve uygulama grupları olmak üzere iki gruba ayrılmıştır. Uygulama gruplarındaki larvaların, bakır oksit nanopartiküllerinin 10, 100 ve $1000 \mu \mathrm{g} / \mathrm{mL}$ derişimlerini içeren besin içerisinde beslenmeleri sağlanmıştır. Uygulama yapılan her bir grupa 40 adet larva eklenmiştir. Deneyler değişik zamanlarda üçer kez tekrar edilmiş ve bir deney serisinde elde edilen veriler kontrol grubu ile karşılaştırmak suretiyle değerlendirilmiştir.

Antioksidan enzim aktivitelerinin tayini: Uygulamadan sonra kontrol ve uygulama gruplarından 10'ar adet larva diseksiyon için seçilmiştir. Larvalar buz üzerinde 2-3 dakika bekletildikten sonra, \% 95 etil alkol ile dezenfekte edilmiştir. Larvalar sırt kısmı strafora gelecek şekilde sabitlenerek birinci çift torasik bacaklarının 
önünden orta eksen boyunca uzunlamasına mikro makas (Bahadır, düz makas, $16 \mathrm{~cm}$ ) yardımıyla kesilmiştir. İlk önce yağ doku (fat body) bir pens yardımıyla izole edilmiş, daha sonra ön, orta ve son barsak olmak üzere üç bölümden oluşan sindirim kanalından orta barsak ayrılmıştır. İzole edilen yağ doku ve orta barsak, içerisinde homojenizasyon tamponu (20 mM; pH 7.6) bulunan ependorf tüplere aktarılmıştır.

Daha sonra Ultra Torrax cihazında dokular homojenize edilmiştir. Yağ dokunun homojenizasyonunda ise, $50 \mathrm{~W}, 40-50 \mathrm{~s}$ ' de ultrasonik homojenizatör (Bandelin Sonoplus. HD 2070, Berlin, Almanya) kullanılmıştır. Homojenatlar, 500xg' de 15 dakika $\left(+4^{\circ} \mathrm{C}\right)$ santrifüj edilmiş daha sonra süpernatanlar, mitokondriyal fraksiyona katılmak için 45 dakika $\left(4{ }^{\circ} \mathrm{C}\right)$ boyunca 12,000 $\mathrm{x} \mathrm{g}^{\prime}$ de yeniden santrifüj yapılmıştır. Sitosolik fraksiyon, düşük moleküler ağırlıklı proteinleri uzaklaştırmak için Sephadex® G-25 (PD10, Pharmacia) jel kolonları üzerinde saflaştırılmıştır (Gonzalez-Rey vd., 2014). Örnekler enzim aktivitelerinin tayini işlemlerine kadar $-80^{\circ} \mathrm{C}^{\prime}$ de bekletilmiştir.

Antioksidan enzim aktiviteleri (SOD, CAT ve GPx) sirasiyla McCord \& Fridovich (1969), Greenwald, (1985) ve Lawrence \& Burk (1976) 'a göre tespit edilmiştir. AChE aktivitesini belirlemek için, orta barsak ve yağ doku, $\% 10$ Triton içeren Tris-HCl tamponu (100 mM, pH 8.0) içinde buz üzerinde homojenize edilmiştir. Daha sonra $12.000 \mathrm{x}$ g' de 30 dakika $\left(4^{\circ} \mathrm{C}\right)$ santrifüj edilmiştir. AChE aktivitesi, Ellman vd. (1961) tarafindan uygulanan metot kullanılarak belirlenmiştir. GST aktivitesi, Habig vd. (1974) yöntemine göre spektrofotometrik olarak ölçülmüștür. Protein miktarının tespitinde ise, substrat olarak Bovine serum albümini kullanılarak Bradford (1976) yöntemine göre belirlenmiştir.

Ístatistiksel analiz: Kontrol grubu ve bakır oksit nanopartikülleri uygulanmış gruplar arasındaki istatistiksel veriler SPSS 21 programında Student Newman Keul's (SNK) testi kullanılarak değerlendirilmiştir. $p<0,05$ değeri istatistiksel olarak anlamlı kabul edilmiştir.

\section{BULGULAR}

\section{Bakır}

oksit

nanopartiküllerinin

karakterizasyonu: Çalışmada kullanılan bakır oksit nanopartikülleri boyut ve şekilsel analizleri TEM, DLS ve ELS yöntemleri ile belirlenmiştir. Karakterizasyona ait veriler Tuncsoy vd. (2019) ayrıntılı olarak verilmiştir.

Bakır oksit nanopartiküllerinin antioksidan enzim aktiviteleri üzerine etkisi: Bakır oksit nanopartiküllerinin farklı derişimlerinin G. mellonella larvalarının yağ doku ve orta barsağındaki CAT aktivitesi üzerine etkileri Şekil 1' de gösterilmiştir. Elde edilen verilere göre hem yağ doku hem de orta barsaktaki tüm uygulama gruplarında $(10,100$ ve $1000 \mu \mathrm{g} / \mathrm{mL})$ CAT aktivitesinde önemli bir azalma meydana geldiği belirlenmiştir . Orta barsak ve yağ dokuda $10 \mu \mathrm{g} / \mathrm{mL}$ bakır oksit nanopartikülü uygulanan gruplarda CAT aktivitesi sırasıyla $\% 85,8$ ve $\% 75,5$ oranlarında azalırken, 1000 $\mu \mathrm{g} / \mathrm{mL}$ bakır oksit nanopartikül uygulaması yapılan gruplarda bu azalma sirasiyla \% 94,2 ve \% 69 olarak tespit edilmişstir.

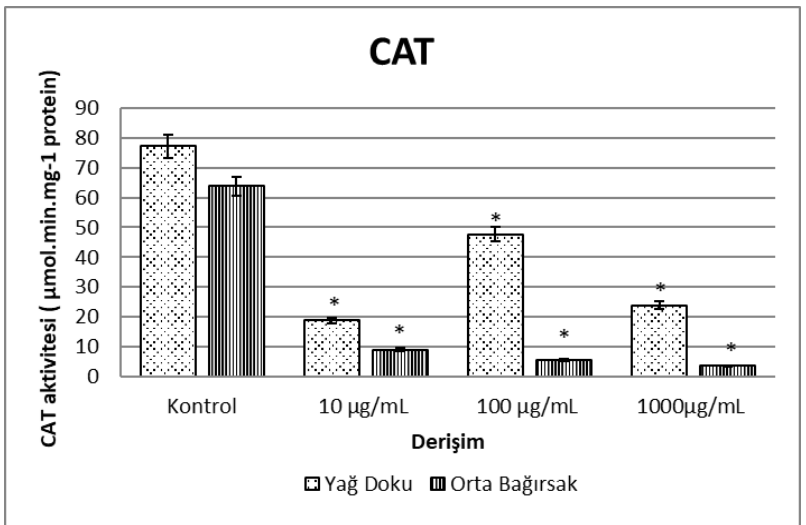

Şekil 1. Bakır oksit nanopartiküllerine maruz bırakılan $G$. mellonella larvalarının orta barsak ve yağ dokusundaki CAT aktivitesi. SNK testine göre “*” ile gösterilenler arasında istatistiksel bir fark bulunmuştur. $(\mathrm{P}<0,05)$.

Figure 1. CAT activity in midgut and fat body of G. mellonella larvae exposed to $\mathrm{CuO}$ NPs. According to the SNK test, a statistical difference was found between those indicated with "*" $(\mathrm{P}<0.05)$

Elde edilen verilere göre bakır oksit nanopartikülünün farklı konsantrasyonlarının $G$. mellonella larvalarının orta barsak ve yağ dokusundaki SOD aktivitesine olan etkileri Şekil 2'de verilmiştir.

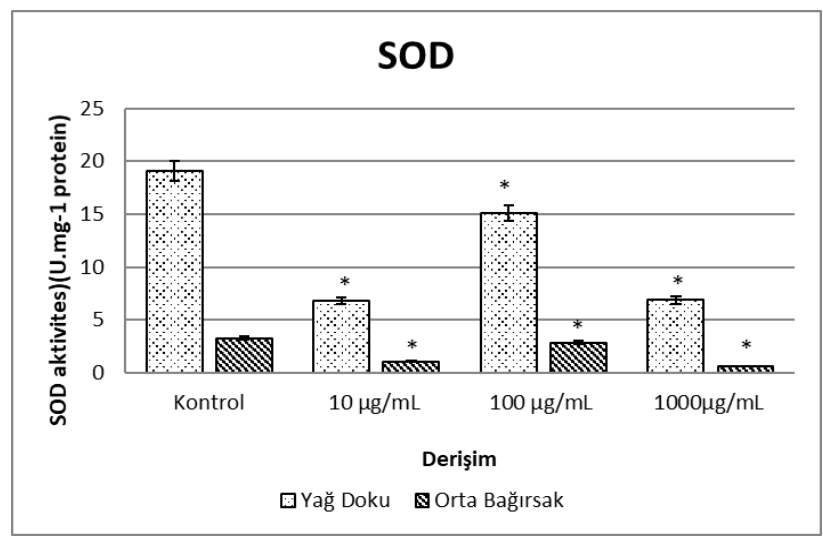

Şekil 2. Bakır oksit nanopartiküllerine maruz bırakılan $G$. mellonella larvalarının orta barsak ve yağ dokusundaki SOD aktivitesi. SNK testine göre “*” ile gösterilenler arasında istatistiksel bir fark bulunmuştur $(\mathrm{P}<0,05)$.

Figure 2. SOD activity in midgut and fat body of $G$. mellonella larvae exposed to $\mathrm{CuO}$ NPs. According to the SNK test, a statistical difference was found between those indicated with "*" $(\mathrm{P}<0,05)$

İstatistiki verilere göre larvaların her iki dokusundaki SOD aktivitesi de tüm uygulama gruplarında 
$(10,100$ ve $1000 \mu \mathrm{g} / \mathrm{mL})$ kontrole göre istatistiki olarak anlamlı bir azalma göstermiştir. Orta barsak ve yağ dokuda $10 \mu \mathrm{g} / \mathrm{mL}$ bakır oksit nanopartikülü uygulanan gruplarda SOD aktivitesi sirasıyla \% 68 ve \% 64,5 oranlarında azalırken, $1000 \mu \mathrm{g} / \mathrm{mL}$ bakır oksit nanopartikül uygulaması yapılan gruplarda bu azalma sirasıyla \% 80,6 ve $\% 64,2$ olarak belirlenmiştir.

Farklı konsantrasyonlarda uygulanan bakır oksit nanopartikülünün G. mellonella larvalarının orta barsak ve yağ dokusundaki GPx aktivitesindeki değişimler Şekil 3' de verilmiştir. Elde edilen istatistiki verilere göre $10 \mu \mathrm{g} / \mathrm{mL}$ bakır oksit nanopartikülü uygulanan gruplarda kontrole göre orta barsak ve yağ dokuda sirasiyla $\% 36,2$ ve $\% 42$ oranlarında önemli bir azalma gözlenirken, $1000 \mu \mathrm{g} / \mathrm{mL}$ bakır oksit nanopartikülü uygulanan gruplarda bu azalma sırasıyla \% 18,2 ve \% 30,5 olarak belirlenmiştir. 100 $\mu \mathrm{g} / \mathrm{mL}$ uygulama grubunda ise her iki dokuda da sirasıyla $\% 54,3$ ve \% 66,6 oranlarında anlamlı bir artış meydana geldiği tespit edilmiştir.

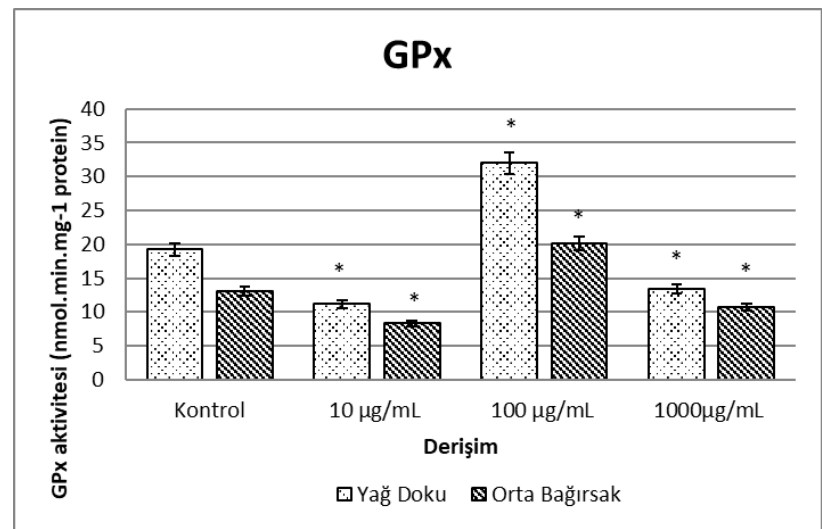

Şekil 3. Bakır oksit nanopartiküllerine maruz bırakılan $G$. mellonella larvalarının orta barsak ve yağ dokusundaki GPx aktivitesi. SNK testine göre “*” ile gösterilenler arasında istatistiksel bir fark bulunmuştur. $(\mathrm{P}<0,05)$.

Figure 3. GPx activity in midgut and fat body of G. mellonella larvae exposed to $\mathrm{CuO}$ NPs. According to the SNK test, a statistical difference was found between those indicated with "*" $(\mathrm{P}<0.05)$

Bakır oksit nanopartikülünün $G$. mellonella larvalarının yağ doku ve orta bağırsağındaki GST enzim aktivitesindeki değişimler Şekil 4' de gösterilmiştir. GST aktivitesinde 100 ve $1000 \mu \mathrm{g} / \mathrm{mL}$ bakır oksit nanopartikül uygulaması sonucunda istatistiki açıdan önemli bir artış meydana gelirken, yağ dokuda tüm uygulama gruplarında azalma meydana geldiği tespit edilmiştir. Orta barsakta meydana gelen GST aktivitesindeki artış $100 \mu \mathrm{g} / \mathrm{mL}$ bakır oksit nanopartikülü uygulanan grupta \% 133,3, 1000 $\mu \mathrm{g} / \mathrm{mL}$ bakır oksit nanopartikülü uygulanan grupta ise $\%$ 60,6 oranında artmıştır.

AChE aktivitesinde istatiksel olarak her iki dokuda da kontrole göre tüm uygulama gruplarında (10, 100 ve $1000 \mu \mathrm{g} / \mathrm{mL}$ ) azalma meydana geldiği belirlenmiştir (Şekil 5). Bu azalma orta barsakta tüm uygulama gruplarında sirasiyla \% 76, \% 10 ve \% 42,4 olarak tespit edilirken, yağ dokuda ise sirasıyla \% 51,7, \% 9,78 ve $\% 42,1$ olarak belirlenmiştir.

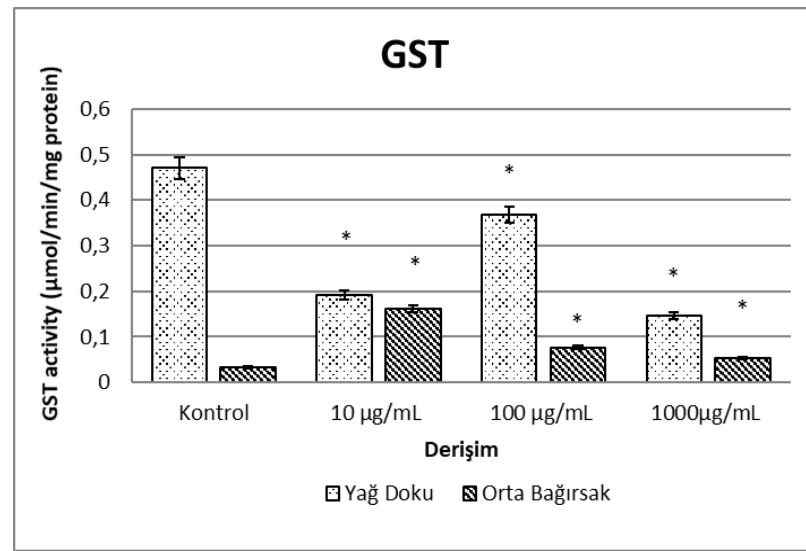

Şekil 4. Bakır oksit nanopartiküllerine maruz bırakılan $G$. mellonella larvalarının orta barsak ve yağ dokusundaki GST aktivitesi. SNK testine göre “*” ile gösterilenler arasında istatistiksel bir fark bulunmuştur. $(\mathrm{P}<0,05)$.

Figure 4. GST activity in midgut and fat body of G. mellonella larvae exposed to $\mathrm{CuO}$ NPs. According to the SNK test, a statistical difference was found between those indicated with "*" $(\mathrm{P}<0.05)$

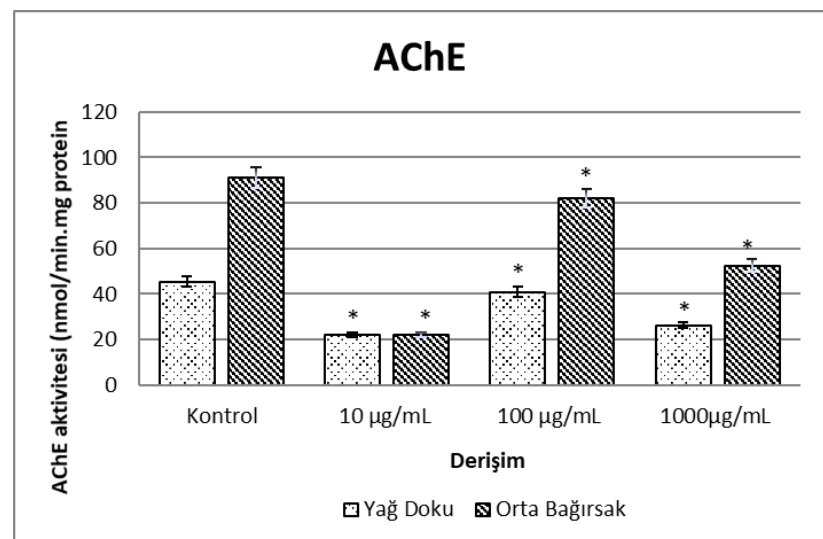

Şekil 5. Bakır oksit nanopartiküllerine maruz bırakılan $G$. mellonella larvalarının orta barsak ve yağ dokusundaki $\mathrm{AChE}$ aktivitesi. SNK testine göre “*” ile gösterilenler arasında istatistiksel bir fark bulunmuștur. $(\mathrm{P}<0,05)$.

Figure 5. AChE activity in midgut and fat body of G. mellonella larvae exposed to $\mathrm{CuO}$ NPs. According to the SNK test, a statistical difference was found between those indicated with "*" $(\mathrm{P}<0.05)$

\section{TARTIŞMA VE SONUC}

Biyolojik zarlardan kolaylıkla geçebilen metal nanopartiküller, DNA hasarı, oksidatif stres, membran hasarı ve moleküler düzeyde organ, doku ve hücrede protein yanlış katlanması gibi olumsuz etkilere neden olabilmektedirler (Aschberger vd., 2011; Schrand vd., 2010). Serbest radikaller, vücutta sürekli olarak oluşan ve antioksidan savunma sistemi tarafindan yok edilen moleküllerdir ve canlılardaki bu zararlı radikallere karşı 
vücutta gelişen bazı enzimatik sistemler vardır. SOD, CAT, GPx gibi enzimler, ağır metal toksisitesinin neden olduğu serbest radikallerin zararlı etkilerine karşı vücudu korumaktadır. Bu gibi biyokimyasal parametreler metal toksisitesi için iyi birer biyomarkırdır. Yapılan çalışmada G. mellonella larvalarının orta barsak ve yağ dokusunda uygulanan tüm derişimlerde SOD ve CAT aktivitelerinde azalma meydana gelirken, orta barsakta GST aktivitesinde artış meydana geldiği gözlenmiştir. GPx aktivitesinde ise, $100 \mu \mathrm{g} / \mathrm{mL}$ derişiminin uygulandığ 1 grupta artış meydana geldiği tespit edilmiştir. Bakır oksit nanopartikül toksisitesinin antioksidan SOD ve CAT seviyelerini azaltarak larvanın orta barsak ve yağ dokusunda reaktif oksijen türlerinin birikmesine neden olmuş olabileceği düşünülmektedir. Assadian vd. (2018) yaptıkları bir çalışmada bakır oksit nanopartiküllerinin in vitro sitotoksik etkisi sonucunda oksidatif stres indüksiyonu ile hücre içi reaktif oksijen türlerinin seviyelerinde önemli bir artış meydana geldiğini bildirmiş̧lerdir. Musca domestica ile yapılan bir çalışmada, farklı konsantrasyonlarda gümüş ve kitosan nanopartikülleri uygulanması sonucunda larvaların SOD, CAT, GPx ve GST aktivitelerinin maruz kalma süresine bağlı olarak değiştiğini tespit etmişlerdir (Ramadan vd., 2020). S. litura ve A. janata ile yapılan bir çalışmada, gümüş nanopartikülü uygulaması sonucunda SOD, CAT ve GPx aktivitelerinin derişime bağlı olarak değiștiğini bildirmişlerdir (Yasur \& Pathipati, 2015). Apis mellifera ile yapılan bir çalışmada ise, arıların 10 gün boyunca çinko oksit nanopartiküllerine ve çinko klorüre maruz bırakılmasından sonra GST aktivitesinde artış meydana geldiğini bildirilmiştir (Milivojevic vd., 2015). Böceklerde nanopartiküller dış iskelete ve hücre içi boşluğa girebilir ve daha sonra nanopartikül iyonları sitoplazmaya salınır ve kükürt proteinlerine bağlanır, böylece reaktif oksijen türlerinin seviyelerinin artmasına ve dolayısıyla hücresel fonksiyonların hasarına ve bunun sonucunda da hücre ölümüne neden olabilmektedir (Benelli, 2018; Mir vd., 2020). Elde edilen bulgular sonucunda bakır oksit nanopartiküllünün neden olduğu oksidatif stres sonucunda dokularda biriken reaktif oksijen türlerinin GPx ve GST enzimleri vasitasiyla ortadan kaldırılmaya çalışıldığı düşünülmektedir.

Farklı derişimlerdeki bakır oksit nanopartiküllerine maruz bırakılan larvalarda ise her iki dokuda da AChE aktivitesinde azalma meydana gelmiştir. Bakırın sülfür verici gruplara olan yüksek afinitesi, tiyol kalıntılarına bağlanarak AChE inhibisyonuna neden olabilmektedir (Gomes vd., 2011). AChE enzim aktivitesindeki değişiklikler, bakır dahil çeşitli metal ve organofosforlu pestisitlere maruz kalındığının bir göstergesidir (Bebiaanno vd., 2004; Lehtonen \& Leiniö 2003; Regoli \& Principato 1995). Böceklerde AChE aktivitesi genellikle beyin, göğüs ve karın bölgeleri ile abdominal ganglionlarda düzenlenmektedir (Thany vd., 2010). AChE aktivitesi, bir organizmanın sinir sisteminin kolinerjik fonksiyonlarını belirlemek için kullanılan bir yöntemdir. Ayrıca, farklı türlerle yapılan çalışmalarda da AChE aktivitesindeki değiş̧ikliklerin oksidatif stres, hücre sinyalindeki düzensizlik veya nörotransmisyondaki bozukluktan kaynaklandığı bildirilmiştir (Gonçalves vd., 2012; Milivojevic vd., 2015).

Böcekler, karasal ekosistemin büyük bir popülasyonunu oluşturan canlı gruplarıdır. Metal nanopartiküllerinin biyoakümülasyonu ve biyomagnifikasyonu bu canlı gruplarında büyük önem taşımaktadır. Nanomalzemelerin biyoakümülasyonu, organizmada nanopartiküllerin birikmesiyle başlamakta ve daha sonra besin zinciri yoluyla diğer organizmalara aktarılmaktadır. Bu nedenle böcekler bu zincirin önemli bir parçasını oluşturmakta ve böceklerin model organizma olarak kullanıldığı çalışmalar önem taşımaktadır. Sonuç olarak yapılan çalışmada da elde edilen veriler, farklı derişimlerde bakır nanopartiküllerine maruz kalan $G$. mellonella larvalarının antioksidan enzimlerinde önemli değişiklikler meydana getirdiği belirlenmiştir. Bakır oksit nanopartikülünün etkisi sonucunda reaktif oksijen türlerinin dokularda artması nedeniyle larvaların orta barsak ve yağ dokularında oksidatif stres meydana geldiği düşünülmektedir. G. mellonella' da bakır nanopartiküllerinin etkisindeincelenen antioksidan savunma sistemi parametrelerindeki değişikliklerin metal kirliliğinin bir göstergesi olarak kullanılabileceği sonucuna varılmıştır.

\section{KAYNAKLAR}

Aschberger, K., Micheletti, C., Sokull-Klüttgen, B. \& Christensen, F.M. (2011). Analysis of currently available data for characterising the risk of engineered nanomaterials to the environment and human health-Lessons learned from four case studies. Environment International, 37, 11431156. DOI: 10.1016/j.envint.2011.02.005

Assadian, E., Zarei, M.H., Gilani, A.G., Farshin, M., Degampanah, H. \& Pourahmad, J. (2018). Toxicity of copper oxide (cuo) nanoparticles on human blood lymphocytes. Biological Trace Element Research 184(2), 350-357.

Bebianno, M.J., Géret, F., Hoarau, P., Serafim, M.A., Coelho, M.R., Gnassiabarelli, M. \& Roméo, M. (2004). Biomarkers in Ruditapes decussatus: a potential bioindicator species. Biomarkers, 9(45), 305-330. DOI: 10.1080/13547500400017820

Benelli, G. (2018). Mode of action of nanoparticles against insects. Environmental Science and Pollution Research, 25, 12329-12341. DOI: 10.1007/s11356-018-1850-4

Bi, J.L. \& Felton, G.W. (1995). Foliar oxygen stress and insect herbivory: primary compounds, secondary 
metabolites and reactive oxygen species as components of induced resistance. Journal of Chemical Ecology, 21, 1511-1530. DOI: 10.1007/BF02035149

Boyles, M.S., Ranninger, C., Reischl, R., Rurik, M., Tessadri, R., Kohlbacher, O., Duschl, A. \& Huber, C.G. (2016). Copper oxide nanoparticle toxicity profiling using untargeted metabolomics. Particle and Fibre Toxicology, 13, 49. DOI: 10.1186/s12989-016-0160-6

Bradford, M. (1976). A rapid and sensitive method for the quantitation of microgram quantities of protein utilizing the principle of protein-dye binding. Analytical Biochemistry, 72, 248-254. DOI: 10.1006/abio.1976.9999

Bronskill, J. (1961). A cage to simplify the rearing of the greater wax moth, Galleria mellonella (Pyralidae). Journal of the Lepidopterists Society, 2, 102-104.

Ellman, G.L., Courtney, K.D., Andres, V. \& Featherstone, R.M. (1961). A new and rapid colorimetric determination of acetylcholinesterase activity. Biochemical Pharmacology, 7, 88-95. DOI: 10.1016/00062952(61)90145-9

Gomes, T. (2012). Effects of nanoparticles exposure in the mussel Mytzlus Galloprovincialis. Thesis, Faculdade De Ciências E Tecnologia, Universidade do Algarve, Portugal.

Gonçalves, J.F., Nicoloso, F.T., da Costa, P., Farias, J.G., Carvalho, F.B., da Rosa, M.M., Gutierres, J.M., Abdalla, F.H., Pereira, J.S., Dias, G.R., Barbosa, N.B., Dressler, V.L., Rubin, M.A., Morsch, V.M. \& Schetinger, M.R. (2012). Behavior and brain enzymatic changes after long-term intoxication with cadmium salt or contaminated potatoes. Food and Chemical Toxicology, 50, 3709-3718. DOI: 10.1016/j.fct.2012.07.016

Gonzalez-Rey, M., Mattos, J.J., Piazza, C.E., Bainy, A.C.D. \& Bebianno, M.J. (2014). Effects of active pharmaceutical ingredients mixtures in mussel Mytilus galloprovincialis. Aquatic Toxicology, 153, 12-26. DOI: 10.1016/j.aquatox.2014.02.006

Greenwald, R.A. (1985). Handbook of methods for oxygen radical research. CRC Press: Boca Raton, Florida, United States of America, s. 447. DOI: 10.1201/9781351072922

Habig, W.H., Pabst, M.J. \& Jakoby, W.B. (1974). Glutathione S-transferases: The first enzymatic step mercapturic acid formation. Journal of Biological Chemistry, 249, 7130-7139. DOI: 10.1042/bj2150617

Hannig, M., Kriener, L., Hoth-Hannig, W., BeckerWillinger, C. \& Schmidt, H. (2007). Influence of nanocomposite surface coating on biofilm formation in situ. Journal of Nanoscience and Nanotechnology, 7, 4642-4648. DOI: 10.1166/jnn.2007.005
Ivask, A., Juganson, K., Bondarenko, O., Mortimer, M., Aruoja, V., Kasemets, K., Blinova, I., Heinlaan, M., Slaveykova, V. \& Kahru, A. (2014). Mechanisms of toxic action of $\mathrm{Ag}, \mathrm{ZnO}$ and $\mathrm{CuO}$ nanoparticles to selected ecotoxicological test organisms and mammalian cells in vitro: A comparative review. Nanotoxicology, $\quad 8, \quad 57-71 . \quad$ DOI: 10.3109/17435390.2013.855831

Lawrence, R.A. \& Burk, R.F. (1976). Glutathione peroxidase activity in selenium-deficient rat liver. Biochemical and Biophysical Research Communications, 71(4), 952-958. DOI: 10.1016/0006-291x(76)90747-6

Lehtonen, K.K. \& Leiniö, S. (2003). Effects of exposure to copper and malathion on metallothionein levels and acetylcholinesterase activity of the mussel Mytilus edulis and the clam Macoma balthica from the Northern Baltic Sea. Bulletin of Environmental Contamination and Toxicology, 71, 489-496. DOI: 10.1007/s00128-003-8853-6

McCord, J.M. \& Fridovich, I. (1969). Superoxide dismutase. An enzymic function for erythrocuprein (hemocuprein). Journal of Biological Chemistry, 244(22), 6049-6055.

Milivojevic, T., Glavan, G., Bozic, J., Sepcic, K. \& Mesaric, T. (2015). Neurotoxic potential of ingested $\mathrm{ZnO}$ nanomaterials on bees. Chemosphere, 120, 547-554. DOI: 10.1016/j.chemosphere.2014.07.054

Mir, A.H., Qamar, A., Qadir, I., Naqvi, A.H. \& Begum, B. (2020). Accumulation and trafficking of zinc oxide nanoparticles in an invertebrate model, Bombyx mori, with insights on their effects on immuno-competent cells. Scientific Reports, 10, 1617. DOI: 10.1038/s41598-020-58526-1

Nations, S., Long, M., Wages, M., Maul, J.D., Theodorakis, C.W. \& Cobb, G.P. (2015). Subchronic and chronic developmental effects of copper oxide $(\mathrm{CuO})$ nanoparticles on Xenopus laevis. Chemosphere, 135, 166-174. DOI: 10.1016/j.chemosphere.2015.03.078

Libralato, G., Galdiero, E., Falanga, A., Carotenuto, R., de Alteriis, E. \& Guida, M. (2017). Toxicity effects of functionalized quantum dots, gold and polystyrene nanoparticles on target aquatic biological models: a review. Molecules, 22, 1439. DOI: 10.3390/molecules22091439

Niska, K., Santos-Martinez, M.J., Radomski, M.W. \& Inkielewicz-Stepniak, I. (2015). $\mathrm{CuO}$ nanoparticles induce apoptosis by impairing the antioxidant defense and detoxification systems in the mouse hippocampal HT22 cell line: Protective effect of crocetin. Toxicology in Vitro, 29, 663671. DOI: 10.1016/j.tiv.2015.02.004

Ramadan, R.H., Abdel-Meguid, A.D. \& Emara, M.M. (2020). Effects of synthesized silver and chitosan nanoparticles using Nerium oleander and Aloe vera on antioxidant enzymes in Musca domestica. International Journal on Environmental Sciences, 21, 9-14. DOI: 10.21608/CAT.2020.20921.1036 
Regoli, F. \& Principato, G. (1995). Glutathione, glutathione-dependent and antioxidant enzymes in mussel, Mytilus galloprovincialis, exposed to metals under field and laboratory conditions: implications for the use of biochemical biomarkers. Aquatic Toxicology, 31, 143-164. DOI: 10.1016/0166-445X(94)00064-W

Schrand, A.M., Rahman, M.F., Hussain, S.M., Schlager, J.J., Smith, D.A. \& Syed, A.F. (2010). Metal-based nanoparticles and their toxicity assessment. Wiley interdisciplinary reviews. Nanomedicine and Nanobiotechnology, 2, 544568. DOI: 10.1002/wnan.103

Sezer Tuncsoy, B., Tuncsoy, M., Gomes, T., Sousa, V., Teixeira, M.R., Bebianno, M.J. \& Ozalp, P. (2019). Effects of copper oxide nanoparticles on tissue accumulation and antioxidant enzymes of Galleria mellonella L. Bulletin of Environmental Contamination and Toxicology, 102, 41-346. DOI: $10.1007 / \mathrm{s} 00128-018-2529-8$

Sezer Tuncsoy, B. (2020). Bakır oksit nanopartiküllerinin Galleria mellonella larvaları üzerine immün ve metabolik etkileri. Karaelmas Fen ve Mühendislik Dergisi, $10 \quad$ (1), 53-60. DOI: 10.7212/zkufbd.v10i1.1526

Thany, S.H., Tricoire-Leignel, H. \& Lapied, B. (2010). Identification of cholinergic synaptic transmission in the insect nervous system. Advances in Experimental Medicine and Biology, 683, 1-10. DOI: 10.1007/978-1-4419-6445-8_1

Yasur, J. \& Pathipati, U.R. (2015). Lepidopteran insect susceptibility to silver nanoparticles and measurement of changes in their growth, development and physiology. Chemosphere, 124, 92-102. DOI: 10.1016/j.chemosphere.2014.11.029

Zhou, M., Tian, M. \& Li, C. (2016). Copper-based nanomaterials for cancer imaging and therapy. Bioconjugate Chemistry, 27, 1188-1199. DOI: 10.1021/acs.bioconjchem.6b00156 